\title{
Canine distemper virus ISCOMs induce protection in harbour seals (Phoca vitulina) against phocid distemper but still allow subsequent infection with phocid distemper virus-1
}

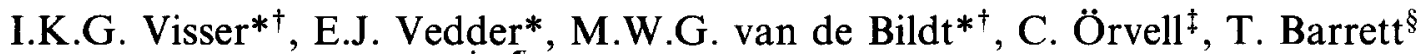 \\ and A.D.M.E. Osterhaus ${ }^{\dagger \infty} \|^{*}$ \\ A candidate canine distemper virus (CDV) ISCOM vaccine has been shown to be effective \\ in protecting harbour seals (Phoca vitulina) from phocid distemper in 1988. However, of \\ the 35 harbour seals receiving this vaccine upon admission to a seal rehabilitation and \\ research centre (Pieterburen, The Netherlands) in 1989, six developed mild inflammatory \\ symptoms of the respiratory tract. Phocid distemper virus-1 (PDV-1) could be isolated \\ from three of these animals. This indicates that the vaccine affords protection from phocid \\ distemper, but may still allow PDV-I infection of the respiratory tract. Contacts with \\ non-vaccinated seals should then be prevented until no more virus is excreted. It is speculated \\ that this PDV-1 infection of the respiratory tract in CDV-ISCOM vaccinated seals is \\ followed by a lifelong immunity.
}

Keywords: Phocid distemper virus; canine distemper virus; ISCOMs; seal; vaccination

During recent disease outbreaks among seals in North West Europe and Siberia in which many thousands of harbour seals (Phoca vitulina) and Baikal seals (Phoca sibirica) died with symptoms similar to those observed in canine distemper, two different morbilliviruses phocid distemper virus-1 (PDV-1) and phocid distemper virus-2 (PDV-2), respectively - were shown to be the primary cause of the outbreaks ${ }^{1-3}$. The viruses were isolated and subsequently characterized on the basis of their biological, morphological, physical, protein chemical and antigenic properties. PDV-1 proved to be a newly recognized member of the genus Morbillivirus, whereas PDV-2 was quite similar if not identical to canine distemper virus (CDV) ${ }^{3}$.

In spite of the antigenic differences between PDV-1 and CDV, it was shown in a vaccination-challenge

\footnotetext{
* Seal Rehabilitation and Research Centre, Hoofdstraat 94a, 9968 AG Pieterburen, The Netherlands. 'Laboratory of Immunobiology, National Institute of Public Health and Environmental Protection, PO Box 1, 3720 BA Bilthoven, The Netherlands. ${ }^{\ddagger}$ State Bacteriological Laboratory, Department of Virology, Karolinska Institute, S-105-21 Stockholm, Sweden. ${ }^{\S}$ Institute for Animal Health, Pirbright Laboratory, Ash Road, Pirbright, Woking GU24 ONF, UK. ${ }^{\infty}$ Division of Virology, Department of Infectious Diseases and Immunology, Veterinary Faculty, State University of Utrecht, Yalelaan 1, 3508 TD Utrecht, The Netherlands. "To whom correspondence should be addressed. (Received 22 July 1991; revised 13 November 1991; accepted 28 November 1991)
}

experiment that harbour seals could be protected from phocid distemper by vaccination with a candidate subunit ISCOM vaccine, based on $\mathrm{CDV}^{4,5}$. In this experiment the sham vaccinated animals developed signs of distemper, including fever, respiratory distress, weight loss and nervous symptoms and died following challenge with PDV-1.

Preventive vaccination with the CDV-ISCOM preparation was then routinely implemented in several captive seal groups including animals in the Seal Rehabilitation and Research Centre (SRRC) in Pieterburen (The Netherlands ). Upon arrival at the SRRC all animals were subjected to a three dose CDV-ISCOM vaccination protocol $^{5}$. In the 4 months before this preventive vaccination was implemented, more than $90 \%$ of all the seals admitted to the SRRC had died from phocid distemper. It was shown that virtually all animals which were CDV-seronegative at arrival had developed morbillivirus-specific virus neutralizing (VN) antibody titres after completion of the vaccination procedure. They all remained free from clinical signs of phocid distemper, indicating that the vaccination had been successful ${ }^{5}$. Survival rates of animals that showed serological evidence of PDV-1 infection upon admission, did not exceed $30 \%$ after using the same vaccination schedule, indicating that postexposure vaccination was far less effective ${ }^{5}$.

In 1989, the year following the massive phocid distemper epidemic in North West Europe, 35 harbour seals were admitted to the SRRC. Each animal was 

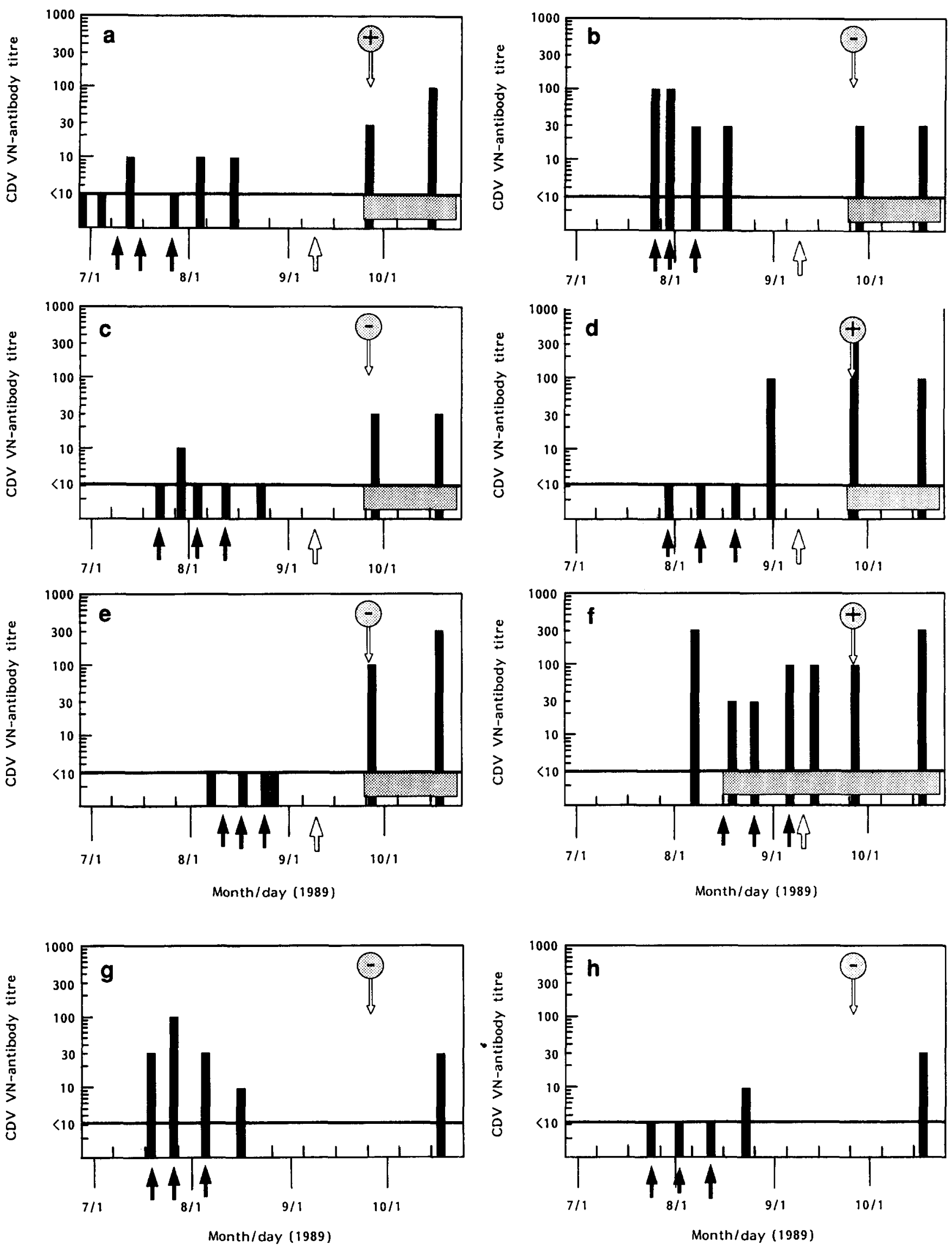

Figure 1 Levels of VN-antibody serum titres to CDV ( 1 ) and presence of mild respiratory symptoms (Bin.t.) in seals at different times after introduction in the SRRC. Seals nos 89-21 (a), 89-27 (b), 89-28 (c), 89-30 (d), 89-33 (e) and 89-34 (f) were kept in the same basin. Seals nos $89-26$ ( $g$ ) and $89-29$ (h) are two of the non-affected animals kept in another basin. The moment of introduction in the SRRC coincides with the first sampling for CDV serology. 4. Vaccination with CDV-ISCOM; 4 , introduction of seal no. $89-34$ into the group of five seals developing clinical symptoms; 8 , demonstration of PDV-1 in swab from nose and pharynx; $\Phi$, no demonstration of virus in swab from nose and pharynx 
Table 1 Reactivity of monoclonal antibodies (mAbs) raised against canine distemper virus (CDV, Convac strain ${ }^{\circ}$ ) and phocid distemper virus (PDV[-1], reference strain') with Vero cell lysates infected with PDV isolated from seals nos $89-21,89-30$ and $89-34$ as tested in an indirect ELISA

\begin{tabular}{|c|c|c|c|c|c|c|}
\hline \multirow[b]{2}{*}{$\begin{array}{l}\text { mAb } \\
\text { no. }\end{array}$} & \multirow[b]{2}{*}{$\begin{array}{l}\text { Raised" } \\
\text { against }\end{array}$} & \multicolumn{5}{|c|}{ Virus strain/isolate } \\
\hline & & $\begin{array}{l}\text { CDV } \\
\text { (Convac) }\end{array}$ & $\begin{array}{l}\text { PDV-1 } \\
\text { ref. strain }\end{array}$ & $\begin{array}{l}\text { PDV } \\
\text { no. } 89-21\end{array}$ & $\begin{array}{l}\text { PDV } \\
\text { no. } 89-30\end{array}$ & $\begin{array}{l}\text { PDV } \\
\text { no. } 89-34\end{array}$ \\
\hline 3.564 & CDV NP & + & - & - & - & - \\
\hline 3.662 & CDV NP1 & + & - & - & - & - \\
\hline 3.721 & CDV NP1 & + & - & - & - & - \\
\hline 3.755 & CDV NP & + & + & + & + & + \\
\hline 3.805 & CDV NP2 & + & + & + & + & + \\
\hline 3.851 & CDV NP & + & + & + & + & + \\
\hline 3.958 & CDV NP3 & + & + & + & + & + \\
\hline 3.991 & CDV NP4 & + & - & - & - & - \\
\hline 4.100 & CDV NP5 & + & + & + & + & + \\
\hline 4.271 & CDV NP & + & + & + & + & + \\
\hline $1.064 \mathrm{C5}$ & PDV NP1 & - & + & + & + & + \\
\hline $1.069 \mathrm{G} 2$ & PDV NP2 & - & + & + & + & + \\
\hline 3.568 & CDV P2 & + & + & + & + & + \\
\hline 3.630 & CDV P & + & - & - & - & - \\
\hline 3.695 & CDV P3 & + & - & - & - & - \\
\hline 3.698 & CDV P1 & + & + & NT & NT & NT \\
\hline 3.768 & CDV P & + & + & - & + & - \\
\hline 3.780 & CDV P4 & + & + & - & + & - \\
\hline 3.788 & CDV P & + & + & + & + & + \\
\hline 4.051 & CDV P5 & + & - & - & - & - \\
\hline 4.088 & CDV P6 & + & + & - & + & - \\
\hline 4.149 & CDV P1 & + & + & + & + & + \\
\hline 4.415 & CDV P1 & + & + & + & + & $t$ \\
\hline 4.174 & CDV P1 & + & + & + & + & + \\
\hline 1.347 & CDV H1 & + & + & + & + & + \\
\hline 2.267 & CDV H2 & + & - & - & - & - \\
\hline 3.734 & CDV H3 & + & - & - & - & - \\
\hline 3.775 & CDV H4 & + & - & - & - & - \\
\hline 4.074 & CDV H5 & + & + & + & + & + \\
\hline 4.275 & CDV H6 & + & - & - & - & - \\
\hline 4.941 & CDV H7 & + & - & - & - & - \\
\hline $1.062 \mathrm{G} 5$ & PDV H1 & - & + & + & + & + \\
\hline $1.063 \mathrm{C} 3$ & PDV H1 & - & + & + & + & + \\
\hline $1.063 \mathrm{E} 9$ & PDV H1 & - & + & + & + & + \\
\hline 1.067E5 & PDV H2 & - & + & + & + & + \\
\hline $1.068 \mathrm{~F} 2$ & PDV H3 & - & + & + & + & + \\
\hline $1.069 \mathrm{Dg}$ & PDV H1 & + & + & + & + & + \\
\hline $1.070 \mathrm{~B} 5$ & PDV H4 & - & + & + & + & + \\
\hline 1.07 tE5 & PDV H1 & - & + & + & + & + \\
\hline $1.072 \mathrm{C} 4$ & PDV H4 & - & + & + & + & + \\
\hline $1.085 \mathrm{C} 4$ & PDV H5 & - & + & + & + & + \\
\hline 1.122D11 & PDV $\mathrm{H} 6$ & + & + & + & + & + \\
\hline 3.551 & CDV F2 & + & + & + & + & + \\
\hline 3.584 & CDV F2 & + & + & + & + & + \\
\hline 3.633 & CDV F1 & $t$ & + & + & + & + \\
\hline 3.697 & CDV F2 & + & + & + & + & + \\
\hline 4.068 & CDV F2 & + & + & + & + & + \\
\hline 4.985 & CDV F3 & + & - & - & - & - \\
\hline 5.086 & CDV F1 & + & + & + & + & + \\
\hline 5.148 & CDV F3 & + & + & + & + & + \\
\hline $1.062 E 2$ & PDV F1 & + & + & + & + & + \\
\hline $1.067 \mathrm{D} 2$ & PDV F2 & + & + & + & + & + \\
\hline $1.068 B 2$ & PDV F1 & + & + & + & + & + \\
\hline $1.062 \mathrm{G}$ & PDV F3 & + & + & + & + & + \\
\hline
\end{tabular}

'NP1-5, nucleoprotein sites 1-5; P1-6, polymerase protein sites 1-6; H1-7, haemagglutinin protein sites 1-7; F1-3; fusion protein sites 1-3.

+ Reactivity in indirect ELISA; - no reactivity in ELISA; NT, not tested

routinely checked for the presence of morbillivirusspecific antibodies upon arrival. Subsequently the animals were kept in quarantine for at least 3 weeks and both the seronegative $(n=20)$ and the seropositive $(n=15)$ seals were vaccinated thrice with the CDV-ISCOM preparation $^{5}$. Four of the seronegative and 13 of the seropositive seals were pups born in 1989. After the quarantine period and completion of the vaccination schedule, five of these pups, one (no. 89-27) which was originally seropositive and four which were originally seronegative (nos 89-21, 89-28, 89-30, 89-33), were gathered in one basin. Seven to thirteen weeks after 
admission they almost simultaneously developed mild respiratory symptoms, including a paroxysmal cough, serous nasal discharge and a conjunctivitis that persisted for more than 2 weeks. This occurred 5-8 weeks after completion of the three-dose vaccination procedure (Figure 1), which was about 2 weeks after the introduction of a sixth seal pup (no. 89-34) into this group of five. This animal, which had also received the standard treatment described above, had been seropositive upon admission, had shown mild respiratory symptoms from the second week onward, but in spite of this was introduced into the group of five.

Standard virus isolation procedures performed with swabs taken from the nose and pharnyx of these six affected and of five non-affected seal pups (nos 89-26, 89-29, 89-35, 89-37 and 89-44) kept in another basin were carried out in primary seal kidney cell (SeKC) cultures with subsequent passaging in Vero cells as previously described $^{3}$. The swabs were taken between 3 and 9 days after the first appearance of clinical signs in the five affected seal pups. Virus infection was demonstrated in the Vero cells inoculated with supernatants from SeKC cultures inoculated with swab materials taken from seal no. 89-34 and from seals no. 89-21 and no. 89-30 by the appearance of typical cytopathic changes and by the presence of virus particles in negative contrast electron microscopy. The three virus isolates were identified as PDV-1 by determining their reactivities with a panel of morbillivirus-specific monoclonal antibodies in enzymelinked immunosorbent assays (ELISA) and immunofluorescence assays (IFA) as shown in Table $1^{3,5,8,9}$. The presence of PDV-1 nucleic acid in RNA extracts from these cultures was shown by Southern blot analysis after amplification of part of the polymerase-associated (P) protein gene of the virus in a polymerase chain reaction using a set of PDV-1 specific primers ${ }^{6.7}$. No virus could be isolated using the same procedure, either from the pups in the control group, or from the three other pups which displayed mild respiratory symptoms. The development of CDV-specific VN antibodies in the six seal pups which displayed respiratory symptoms and in two of the five seal pups which remained healthy - one seropositive and one seronegative upon admission - are given in Figure 1. After completion of the vaccination schedule, these animals had all developed CDV-specific VN antibodies. Seals nos 89-21, 89-27, 89-28, 89-30 and 89-34 had developed a titre of 30 and seal no. 89-33 a titre of 100 . After the onset of the disease the antibody titres of affected seals nos 89-27, 89-28 and 89-30 remained the same (titre $=30$ ), whereas those of affected seals no. 89-21 and no. 89-33 showed a threefold increase. Since in the two non-affected seals (no. 89-26 and no. 89-29) a threefold increase in titre was also observed, it could not be concluded whether this titre rise in the affected animals was related to the observed infection with PDV-1.

From these and our previous data we conclude that vaccination with the candidate CDV-ISCOM vaccine does induce CDV-neutralizing antibodies and protection against the serious disease known as phocid distemper. However, this heterologous vaccination does not induce complete protection against replication of PDV-1 in the respiratory tract, which may apparently result in mild upper respiratory illness. This finding is in agreement with results obtained in previously described protection experiments using other heterologous morbillivirus vaccines. Appel et al. ${ }^{10}$ demonstrated that heterologous vaccination of dogs with live attenuated measles vaccines also induces partial protection against canine distemper. Similarly, we have shown that CDV-ISCOMs induce complete protection in dogs against CDV infection and distemper, whereas measles virus (MV)-ISCOMs only induced partial protection against distemper in dogs ${ }^{11}$ To be able to induce complete protection against phocid distemper and PDV-1 infection by means of vaccination we have considered the development of an homologous PDV-1-ISCOM vaccine. If such a vaccine would also protect against PDV-1 infection of the respiratory tract, this would prevent the threat to non-vaccinated seals imposed by temporary spread of PDV-1. It could, however, be argued that the incomplete but effective protection against phocid distemper afforded by the heterologous CDV vaccine is preferable since it would still allow subsequent infection with PDV-1, resulting in mild upper respiratory disease followed by lifelong immunity, similar to the immunity seen after recovery from other morbillivirus infections. Contacts with nonvaccinated seals should then be prevented until no more virus is excreted.

\section{ACKNOWLEDGEMENTS}

The authors are grateful to Professor Dr B. Morein for helpful suggestions concerning the preparation of the CDV-ISCOM vaccine, the animal attendants and volunteers of the SRRC in Pieterburen (The Netherlands) for their help in collection of the samples and Ms C. Kruyssen and $\mathrm{Mr} \mathrm{R}$. Stokking for their help in preparing the manuscript.

\section{REFERENCES}

1 Visser, I.K.G., Teppema, J.S. and Osterhaus, A.D.M.E. Virus infections of seals and other pinnipeds. Rev. Med. Microbiol. 1991 2, 105-114

2 Osterhaus, A.D.M.E., et al., and Grachev, M.A. et al. Distemper virus in Baikal seals. Nature 1989, 338, 209-210

3 Visser, I.K.G., Kumarev, V.P., Orvell, C., De Vries, P., Broeders, H.W.J., Van de Bildt, M.W.G. et al. Comparison of two morbilliviruses isolated from seals during outbreaks of distemper in North West Europe and Siberia. Arch. Virol. 1990, 111, 149-164

4 Osterhaus, A.D.M.E., Visser, I.K.G., Vedder, E.J., Reijnders, P.J.H., Kuiper, J. and Brugge, H.N. Seal vaccination success. Nature 1989 , 337, 21

5 Visser, I.K.G., Van de Bildt, M.W.G., Brugge, H.N., Reijnders, P.J.H. Vedder, E.J. et al. Vaccination of harbour seals (Phoca vitulina) against phocid distemper with two different inactivated canine distemper virus (CDV) vaccines. Vaccine 1989, $7(6), 521-526$

6 Barrett, T., Crowther, J., Osterhaus, A.D.M.E., Subbarao, S.M. Groen, J., Haas, L. et al. Molecular and serological studies on the recent seal virus epizootics in Europe and Siberia. Sci. Tot. Envir. in press

7 Haas, L., Subbarao, S.M., Harder, T., Liess, B. and Barrett. T. Detection of phocid distemper virus RNA in seal tissues using slot hybridisation and the polymerase chain reaction amplification assay: genetic evidence that the virus is distinct from canine distemper virus. J. Gen. Virol. 1991, 72, 825-832

8 Orvell, C., Shesberadaran, H. and Norrby, E. Preparation and characterisation of monoclonal antibodies directed against four structural components of canine distemper virus. J. Gen. Virol. 1985, 66, $443-456$

9 Orvell, C., Blixenkrone-Möller, M., Svansson, V. and Have, P. Immunological relationships between phocid and canine distemper virus studied with monoclonal antibodies. J. Gen. Virol. 1990, 71, 2085-2092

10 Appel, M.J.G., Shek, W.R., Shesberadaran, H. and Norrby, E. Measles virus and inactivated canine distemper virus induce incomplete immunity to canine distemper. Arch. Virol. 1984, 82, 73-82

11 De Vries, P., UytdeHaag, F.G.C.M. and Osterhaus, A.D.M.E. Canine distemper virus (CDV) immune-stimulating complexes (iscoms), but not measles virus iscoms, protect dogs against CDV infection. J. Gen. Virol. 1988, 69, 2071-2083 